The business session will take place on Sunday morning, April 26, at 9:30 a.m. for the election of officers and transaction of other business.

A large block of rooms has been reserved for members attending the meeting. Reservation cards are being mailed to members along with an advance program of the meeting. Members are urged to make room reservations as early as possible.

Eleanor H. Finch

\title{
CORRESPONDENCE
}

The Editors of the JounNal welcome scholarly communications and will print those considered to be of general interest to its readers.

\section{Letter from Professor Julius Stone}

It is a pleasure to contribute to your newly opened correspondence pages on a matter of honor and title of members of the Society. I notice on page 436 of your July number that my friend Richard Falk has documented his reference to what the State of Israel "will contend," by citing the published text of my recent lecture to the Australian Branch of the International Law Association, which is entitled No Peace-No War in the Middle East (1969).

Since he and I both hold that principles are to be impartially applied, please now permit me to say that it is as gratuitous and wrong for him thus to present my positions as representing official positions of the Government of Israel, as it would be for me or his other colleagues to suggest that many of his recent writings represented official positions of the Republic of North Viet-Nam.

All of us have recognized the single-mindedness with which Professor Falk has sought to clarify and even improve vital segments of international law, and that the effects have been to present arguments often supporting the stances of the Republic of North Viet-Nam. He would properly complain if responses to him implied that, in taking such positions, he was acting as a spokesman of the Republic of North Viet-Nam.

This is not the place to examine Professor Falk's article on the Beirut raid. Others, no doubt, will take the many exceptions to which it seems to me to be open. But perhaps you will permit me to say that the article as a whole seems structured on a most questionable premise, invalidating much of its whole tenor and detail. Professor Falk's arguments proceed on the assumption that the Beirut affair was a case of reprisals in peacetime. He assumes, throughout, that the state of Israel as a Member of the United Nations should be held with meticulous insistence to the duties of the law of peace vis-d-vis certain Arab states, while those states for their part have for twenty years, and right in to the present, steadily pressed forward by active hostilities the openly declared design of destroying the state of Israel.

- See article by Blum, above, p. 73.-ED. 
Surely, also, such a demand cannot be made to sound more sensible by Professor Falk's eyebrow-raising reference to Israel "imposing its will on weaker countries" (page 438). These "weaker" Arab countries have fifty times and more the strength of Israel, whether this be measured in population, territory, or wealth; and their aircraft and armaments, according to the September, 1969, figures of the London Institute of Strategic Studies, are now again more than double those of Israel. The phrase "imposing its will," also sits not at all well with the known facts that the forceful initiatives leading finally to the present position have been taken by the Arab states, within a persistent and continuing design to destroy the state of Israel.

Let me close with a plea to my friend Richard Falk to devote his next study to demonstrating how these past two decades of openly declared efforts of a number of Arab states to destroy the state of Israel can stand with a number of clear obligations. I refer, of course, to those arising from the principles of "sovereign equality of all its Members," of settlement of international disputes "by peaceful means," and that Members shall refrain from "threat or use of force against the territorial integrity or political independence of any State, etc." (Charter, Article 2(1), (3) and (4).) To be so moved to scholarly effort by the Athens-Beirut affair, and remain inactive on the major issues, would be indeed to strain at a gnat and swallow a camel.

In the light of those more basic inquiries, he might wish to revise his present Beirut study. He may even wish to re-examine the indirect (and I am sure unintended) encouragement given by his language concerning "the whole matter of the existence of Israel" on page 443, to unlawful attempts to destroy the state of Israel.

Julius Stone
Sydney, Australia
September 12, 1969

\section{Reply to Professon Julus Stone}

Let me try, as clearly as possible within brief compass, to respond to the principal points raised by Julius Stone's letter.

(1) I did not intend to suggest that Professor Stone was tantamount to a spokesman for the state of Israel, although I now appreciate that my phrasing might have lent itself to such an interpretation. It would have been more correct to report that Israel "has contended" than that it "will contend," and to document such a contention by reference to any number of official statements (e.g., S/PV. 1462, Dec. 31, 1968, p. 52; Mr. Tekoah: "Let no one make the mistake of thinking that the people of Israel might be swayed by inequitable pronouncements."). After such a reference, then, it might be reasonable to cite Professor Stone, as I did, to explain why the Security Council, as constituted, is considered by at least one expert to be an inequitable forum for passing judgments on the Arab-Israeli context.

(2) A more serious, and fundamental, criticism advanced by Professor Stone is that my article rests "on a most questionable premise," namely, 